\title{
Capital Structure and Firm Growth in China
}

\author{
Yan Zhao ${ }^{1}, \&$ Zhiqiang $\mathrm{Ye}^{1}$ \\ ${ }^{1}$ School of Business, East China University of Science and Technology, Shanghai, 200237, China \\ Correspondence: Yan Zhao, 130 Meilong Road, Shanghai, 200237, China.
}

Received: August 14, 2019

Accepted: August 30, $2019 \quad$ Available online: September 24, 2019

doi:10.11114/aef.v6i6.4540

URL: https://doi.org/10.11114/aef.v6i6.4540

\begin{abstract}
Using dynamic GMM method with data from 2003 to 2015, we propose a growth hypothesis of capital structure of Chinese firms, that is, higher growth leads to higher financial leverage. The paper further investigates the impact of external financing constraints on the relationship of growth and leverage, and shows that the firm with tighter financing constraints has a stronger relation between growth and leverage. Finally, the robustness test is conducted in the high-tech industries with financial constraints and high growth. The conclusions of this paper have important implications for both the listed firms and the market regulators.
\end{abstract}

Keywords: capital structure, financing constraints, growth, product market structure

\section{JEL Classification: G00 G32}

\section{Introduction}

Modigliani and Miller's theory suggests that under perfect market conditions, the choice of capital structure will not affect the value of the firm. In the subsequent literature, researchers have relaxed the perfect market hypothesis and accordingly, two other major theories emerge: the trade-off theory and the pecking order theory. Trade-off theory states that the firm will face a trade-off between the tax shield benefit and bankruptcy costs. Pecking order theory argues that, due to the existence of adverse selection, the firm will compare the costs occurred from different financing methods, and typically choose internal financing first, then debt financing, and finally equity financing.

After nearly four decades' reform and opening-up, China's economy and its stock market now rank the second in the world, only after the United States. China's A share has been included into the MSCI emerging market index, and the size of bank assets has become the largest in the world ${ }^{1}$. China's financing system, and in particular the capital structure, however, is different from that of the developed countries.

The factors that influence the capital structure of Chinese listed firms include firm characteristics, macroeconomic environment and industrial policies. The related literature is vast, for example see Huang and Song (2006), Zou and Xiao (2006), Strebulaer(2007), Qian et al.(2009), Pessarossi and Weill(2013), Chang et al.(2014), Danis et al.(2014), Dong et al. (2016), Huang et al. (2016), and Chen and Ling (2017)). Their main findings can be summarized in the following. First, the financial leverages are positive correlated with firm sizes while are negative correlated with profits. Second, financial leverages are positively correlated with the proportions of tangible asset. Third, because the state-owned firms have higher equity financing capacities, they generally display low financial leverages. Forth, different industries, different degrees of competition, different levels of economic development, different (bull or bear) market conditions or different monetary policies, may significantly affect the listed firm's choice of financial leverage.

As for the most important factors, Chang et al. (2014) pointed out that profitability and growth are crucial for the firm's capital structure, and Zou and Xiao (2006) further argued that growth's effect can also be analyzed with the trade-off theory or the pecking order theory. Trade-off theory suggests that higher growth means higher risk and higher financial cost, so the firm with higher growth tends to use more equity financing instead of riskier debt to alleviate this problem, therefore there is negative relationship of growth and financial leverage. Pecking order theory suggests that the firm with high growth faces stronger information asymmetry and chooses debt financing to countermeasure this asymmetry between outer investors and inner managers, so growth and financial leverage are positively correlated.

\footnotetext{
${ }^{1}$ Data source: Financial Times, March 6, 2017.
} 
Empirical studies yield mixed results. Tong and Green(2005), Chang et al.(2014) and Danis and Rettl (2014), for example, found that growth is positively related to financial leverage, but Zou and Xiao (2006) and Hovey (2007) gave opposite conclusions. Huang and Song (2006) obtained both positive and negative correlations in their paper. The empirical results of Qian et al. (2009), however, showed that growth has no significant effect on financial leverage.

Though previous studies did try to investigate the influence of growth on the capital structure of firms, most of them treat growth as exogenous without more detailed investigation. This paper tries to fix this problem, and thus is closely related to Gaur et al. (2013) and Jiang et al. (2015), in which firm growth is endogenously analyzed. The former is from the perspective of M\&A, and the latter is from product market competition. Gaur et al. (2013) put forward the growth probability hypothesis, suggesting that China is an emerging market and thus Chinese firms have a huge growth opportunity. M\&A is a strategic tool, not only for growth, but also for China's stock market's privatization. Besides, the Chinese government has an informal goal to let more Chinese firms to be listed into the "Global 500". Therefore, whether horizontal or vertical, $M \& A$ can send a signal of the future potential growth.

Jiang et al. (2015), on the other hand, argue that product competitiveness and investment are significantly correlated with each other under a high and predictable growth environment like China. According to the real option theory, when a project is not determined by the firm's intrinsic characteristic, the waiting option devalues under the competition. China's predictable high growth reduces the uncertainty of waiting option and accordingly, the value of it. Therefore, in order to pursue the first-mover advantage, the firm will choose immediate investment, resulting in a positive investment-competition correlation.

We consider growth an important factor in influencing capital structure for Chinese firms for the following reason. The past four decades have witnessed burgeoning of China's economy with average annual growth rate as high as $9.8 \%$. In particularly, listed firms, which are generally leading firms in the industries, achieved even higher than average growth. This phenomenon is different with developed economies, in which the growth of listed firms is much lower or uncertain. We believe that in a predictable high growth economy, cost may not be the top concern when choosing financing. This paper indeed shows that the Chinese listed firms prefer debt with higher degree marketization than other options.

Our contributions can be summarized in four aspects. First, according to Gaur et al. (2013) and Jiang et al. (2015), we propose the growth hypothesis of capital structure. A firm compares the value between immediate investment and delayed investment. Because of the predictable high economic growth rate, value of immediate investment is higher and thus preferred in China. Furthermore, we compare the difference in the degree of marketization between the credit market and the stock market. We find that Chinese firms prefer bank credits when the degree of marketization for external financing is higher. Therefore, we claim that the growth and financial leverage are positively correlated.

Second, we investigate the relationships between growth, financial constraints, and capital structure in details. Firms need to decide equity financing or debt financing. When choosing equity financing, the listed companies are faced with more difficulties such as the administrative intervention, the complexity of the procedure, and the long duration for approval. As a result, bank credit has become an important way of financing for listed companies. The differences in financing constraints largely refer to the easiness of accessing bank credit in China. This paper examines the impact of financing constraints on the relationship between capital structure and growth, and finds that when the financing constraints of listed companies are strong, even companies with high growth will have difficulties in obtaining the bank credit financing, which leads to a weakened relationship between capital structure and growth.

Third, following the existing literature that analyze the effect of market competitiveness on company decision-making, we examine the impact of product competition on the relationship between capital structure and growth. The logic is that when the firm is facing a more competitive market environment, the first mover advantage is more significant and thus the firm prefers immediate financing regardless the cost, leading to a higher financial leverage. That is, product market competitiveness and capital structure are positively correlated.

Fourth and the last, we use dynamic GMM model for empirical testing. Most researchers adopt the multiple cross-sectional regression models to study factors influencing the capital structure. However, as Barraclough (2007), Zhu (2012) and Chen (2014) has noted, this leads to false regression and may also cause endogeneity. In addition, this approach often uses the capital structure index as the financial leverage, which measures only the cumulative effect of historical financing decision, and thus cannot serve the purpose of analyzing a certain influencing factor well. Wintoki et al. (2012), instead, proposes that the dynamic panel GMM model can better solve these problems. Applying dynamic panel GMM model to test the capital structure of Chinese listed companies is still rare, and our study will enrich the related literature. 


\section{Institutional Background and Research Hypotheses}

\subsection{Institutional Background}

\subsubsection{Debt Financing}

As a transitional economy, China has unique institutional characteristics, which significantly differ from other countries in terms of degree of marketization, ownership structure of financial institutions, government regulation and other aspects.

Since China's reform and opening-up policy, the People's Bank of China (PBOC) has divested its commercial bank functions, policy bank functions and monitoring functions to other banks to focus on central bank functions. Following this shift, a banking system with five state-owned commercial banks at the core, and supplemented by national joint-stock commercial banks, regional city commercial banks, rural credit cooperatives and foreign banks has gradually taken shape. Because China had been a planned economy (instead of the market economy) before, there were some innate problems such as regional and industrial segmentation and serious administrative intervention from the government.

The entry of WTO urged China to reform its banking system. As a price paid for being a new member of WTO, China committed itself to fully open the banking sector to foreign-invested banks after five years of protection period as of 2011. To prepare for this competition, China's commercial banks had already accelerated their reform. "Law on Operation of Commercial Banks" in 1995 requires commercial banks to strengthen their credit risk management, gradually reduce or even stop loans to uncompetitive state-owned enterprises (SOEs) upon the administrative order of the government. The effects of this law were impressive ( $\mathrm{Li}, 2011)$.

Apart from legislation, China has also turned to other measures to reform its banking system, including capital injection for state-owned enterprises, establishment of a special monitoring institution, implementation of new accounting standards, and reduction of state-owned share-holding. Central Hujin Investment Ltd. was founded in 2003 and it injected foreign exchange reserves into four state-owned commercial banks, including 22.5 billion USD into the Bank of China (BOC) in October 2003, 20 billion USD into China Construction Bank (CCB) in December 2003, 15 billion USD into the Industrial and Commercial Bank of China (ICBC) in April, and 19 billion USD into the Bank of Agriculture (BOA) in November 2008.

April 25, 2003 witnessed the establishment of China Banking Regulatory Commission (CBRC), which is a ministry-level institution directly subordinate to the State Council. Authorized by the State Council, the CBRC was responsible for monitoring and managing banks, financial asset management companies, trust investment companies and other deposit-type financial institutions; and maintaining legitimate and steady operation of the banking industry. The goal of CBRC was to strengthen the monitoring role and improve the overall competitiveness of domestic banks.

On January 1, 2007, "New Version of Accounting System for Business Enterprises" was put into force. Definitions of accounting items in the new system are geared to the international practices. Not only does the "New Version of Accounting System for Business Firm" bring dramatic changes to accounting, but also it lifts risk control, information, disclosure, information system and corporate governance of commercial banks to a new level.

Foreign investors or banks are only allowed to hold a small percentage of state-owned shares. In 2005, the Bank of America and Temasek Holdings invested 3 billion USD and 2.5 billion USD to hold 9\% and 6\% of the China Construction Bank (CCB) respectively. Following that, China started to turn its banks from pure state-owned into public holding entities through listing on the A share market of Mainland China and on Hong Kong Exchanges and Clearing Limited (HKEx). On October 27, 2005, the CCB went public on HKEx, and then issued A-shares on September 25, 2007. On June 1, 2016, and July 5, 2006, Bank of China(BOA) Limited successfully listed itself in HKEx and Shanghai Stock Exchange (SSE), subsequently. On October 28, 2006, CBRC synchronously listed itself in HKEx and SSE. On July 15, 2010 and July 16, the BOA listed itself on HKEx and SSE, respectively. The reforms of banking sector are widely regarded to be positive. For example, Chang et al. (2014), Hsiao et al. (2015), Qian et al. (2015) and Dong et al. (2016) studied China's banking sector from the perspective of cost and profitability, credit rating, professionalism of staff, and concluded that the reform of China's banking industry has achieved a huge success.

China's informal financial institutions also provides capital for firms, especially for small and medium-sized firms (SMEs). Credit guarantee is more widely adopted by informal financial institutions instead of mortgage guarantee, which is often adopted by formal financial institutions like banks. This turns out to be an important source of financing for SMES. For example, a survey of 110 SMEs from 20 provinces indicates that the informal financing accounted for $28.07 \%$ of total financing. Dybvig et al. (2011) showed that there had been 15,000 informal financial institutions by the end of 2010, which provided 893 billion RMB of loans for 166,000 firms. To better regulate the informal financing, in 2006, the PBOC issued "Regulations on Lenders" to further specify the identities of lenders, borrowers and range of the interest rates. According to Economic Information Daily on September 22, 2014, the private lending and financing in 
China had exceeded 500 million RMB.

\subsubsection{Equity Financing}

Compared with debt financing, the progress of China's equity financing is deliberately made slow and the government gives direct controls over almost every aspect of the market. On March 17, 1999, CSRC issued "Several Opinions on Further Strengthening Monitoring of Security Firms", requiring that any firm planning to increase shares must be earning profit. This requirement was underlined again in the "Interim Procedures for Listed Firms on Public Offerings" on April 30, 2000. On March 28, 2001, "Regulations for Offering of New Shares by Listed Firms" further required listed firms to distribute dividends. If the listed firms fail to do so, the main underwriter should disclose this in the due diligence report.

On December 8, 2004, "Several Regulations on Strengthening Protection of Rights and Interests of Public Stock Shareholders" clearly stipulated that listed firms that have not distributed cash dividends are neither eligible to issue new shares among the public, nor issue convertible bonds or provide placing for original shareholders. "Policies on dividends for Listed Firms" released on May 6, 2006 specified dividends including cash in more details. "Modifications of Several Regulations on Dividends of Listed Firms" issued on October 9, 2008 amended the year 2006 version and formally required that cash dividends should be cash only, and further raised the ratio of cash in total dividends. In particular, it requires that "the cash dividends in the most recent three years should not be lower than $30 \%$ of the annual average distributable profits realized in the most recent three years".

CSRC also oversees the allotment and seasoned equity offer(SEO) process. According to "Management Methods on Security Offering of Listed Firms" and "Notice on New Equity Offering for Listed Firms", only firms that have profits can use equity financing, and even when their equity financing application are approved, they cannot choose the allotment price and allotment offering quantity. CSRC stipulates detailed requirements on profitability, SEO price, SEO interval and lockup period through frequent orders, policies, or notices. There documents have one thing in common, that is, to limit the size of SEO shares.

Various studies have confirmed that the government regulations are hindering China's equity market. For example, Bo et al. (2011) finds that SEO of listed firms on China's stock market is influenced by administrative intervention not only in terms of the equity offering process, but also in terms of the equity offering pricing. Fonseka et al. (2014) studies private placement regulations issued by CSRC in 2006, and points that these regulations allow CSRC to play a greater role in intervention. Fonseka et al. (2015) focus on political ties for listed firms and argued that firms with strong political ties, which are typical for SOEs, can get approval from CSRC easier and faster.

In short, the reform process of China's debt financing market and equity financing market is unbalanced. China's debt market is more market orientated, but the equity market is subject to strong government regulations. To get the regulation approvals, firms must wait longer or have strong political ties to expedite this process. The strong regulations bring about additional costs for listed firms when considering equity financing.

\subsection{Research Hypotheses}

Traditionally, growths of firms are taken as control variables when studying the capital structure. Growth means valuable investment projects in the future, although it lacks guarantee value because of the future uncertainty. Once a firm cannot keep on operation and loses the growth momentum, it will have to endure the high financial distress cost (Myers, 1977). According to the trade-off theory, the debt level and the growth are negatively correlated. In part, this is because when the firm's growth is higher, insiders who have private information are not willing to share the earnings with outsider creditors. Consequently, the debt ratio tends to fall. Besides, Kim and Welsbach (2008) argue that the high-growth firm has a more uncertain cash flow and its information asymmetry is thus more serious. This requires the firm to choose equity financing to avoid financial distress in the future. Empirical findings of Rajan and Zingales(1995) and Booth et al.(2001) have supported the negative correlation between growth and capital structure.

This conclusion, however, may hold only for market with modest growth. For emerging economies like China, high growth is more likely and thus uncertainty is considered much lesser. According to real options theory, a firm can compare the value of immediate investment and prolonged investment. When the latter is higher than the former, the firm should wait for the next round when the economic situation improves; otherwise, the firm should invest immediately. The rapid growth of China's economy has created a favorable external environment for Chinese firms. Because of high predictability of growth, future growth is more certain ${ }^{2}$. Hence, high-growth firms should take the

\footnotetext{
${ }^{2}$ According to the world bank database, during 2003-2015, the annual growth rate of China's GDP is $9.43 \%$, the standard deviation is $2.13 \%$, standard deviation/mean is 0.226 , the annual growth rate of world's GDP is $2.89 \%$, the standard deviation is $1.63 \%$, standard deviation/mean is 0.566 , the annual growth rate of OECD's GDP is $1.73 \%$, the
} 
immediate investment strategy to increase their value.

There are two financing approaches for Chinese listed firms: debt financing and equity financing. If the listed firm's growth is high and there are many investment opportunities with predictable value, then the listed firm will make use of all financing opportunities to expand the market share first. This suggests that Chinese firms may still prefer debt for fast financing even the cost is high. In developed equity markets where government intervention is rare and the associated waiting time is not long, firms will compare equity financing with debt financing and choose the less costly one, according to the pecking order theory.

The bond market of Chinese firms has not yet been fully developed, and debt financing is dominated by bank loans. Besides, China's bank loans adopt the credit rating method, which can facilitate the listed firms in obtaining loans (Chang et al., 2014). This credit rating system is beneficial for high-growth firms. On the contrary, China's capital market has long implemented strict regulation, and the regulations for equity refinancing of listed firms have not shown any sign to loose. Though China's equity financing cost is low because of its higher price/earnings $(\mathrm{PE})$, financing demands of high-growth listed firms can hardly be met in a timely manner because of the strict regulations.

Therefore, we propose the following main hypotheses:

\section{H1: The higher the firm's growth, the higher the financial leverage for Chinese listed firms.}

External financing of a listed firm will be confronted with different degrees of financing constraints, which are common for Chinese listed firms. When the financing constraints are tight, listed firms will have more difficulties in equity financing from the capital market. As a result, firms with tighter financing constraints will prefer debt financing and thus have high the financial leverages. Therefore, we propose the following hypotheses:

\section{H2: Firms with tighter financing constraints have a stronger correlation between capital structure and growth.}

According to the theory of industrial organization, firms take the response of competitors into their own decision-making. For example, see James and Levis (1986), Wanzenried (2000), Lyandres (2002) and Liu Zhibiao et al. (2003) for theoretical research and Guney et al. (2011), Mitani (2014) for empirical research, who argue that the corporate financial structure depends on the characteristics of the company's specific product market (such as Cournot competition, Bochuan competition and duopoly competition). The higher market competition, the higher return is for first move advantage. This implies that when the market is more competitive, the immediate investment (debt financing) is more valuable and thus preferred, and the financial cost will be less likely to be considered. Therefore, we have the following hypothesis.

\section{H3: The more competitive industry, the higher correlation between firm growth and financial leverage.}

\section{Empirical Model and Data}

Since debt is a continuous variable, we use dynamic GMM method to test the effect of growth on capital structure with controlling both time effect and industry effect. Also, because of the possible endogeneity between capital structure and growth, we adjust by subtracting the industry averages. Based on the hypothesis, we develop the following three empirical models:

$$
\begin{aligned}
& \operatorname{Lev}_{i, t}=\alpha+\beta_{1} \operatorname{Lev}_{i, t-1}+\beta_{2} R_{i, t}+\beta_{3} X_{i, t}+\sum_{j} \gamma \text { Year }_{t}+\sum_{k} \phi \text { Industry }_{k}+\varepsilon_{i, t} \\
& \operatorname{Lev}_{i, t}=\alpha+\beta_{1} \operatorname{Lev}_{i, t-1}+\beta_{2} R_{i, t}+\beta_{3} I_{i, t}+\beta_{4} R_{i, t} * I_{i, t}+\beta_{5} X_{i, t}+\sum_{j} \gamma \text { Year }_{t}+\sum_{k} \phi \text { Industry }_{k}+\varepsilon_{i, t} \\
& \operatorname{Lev}_{i, t}=\alpha+\beta_{1} \operatorname{Lev}_{i, t-1}+\beta_{2} R_{i, t}+\beta_{3} H H I_{i, t}+\beta_{4} R_{i, t} * H H I_{i, t}+\beta_{5} X_{i, t}+\sum_{j} \gamma \text { Year }_{t}+\varepsilon_{i, t}
\end{aligned}
$$

where $\operatorname{Lev}_{\mathrm{i}, \mathrm{t}}$ is the financial leverage(capital-debt ratio) to represent capital structure. $\mathrm{R}$ stands for firm's growth, which can be represented by the growth rate of business revenue and TQ. In the robustness test, $\mathrm{R}$ is changed to the national or provincial economic growth rate. X are control variables including firm size "Size", shareholder's "concentration", firm's tax rate "Taxrate", non-debt tax shield "Ndts", and tangible asset ratio "Tangas". "Year" stands for dummy

standard deviation is $1.76 \%$, standard deviation/mean is 1.017 . So, the growth and stability of Chinese economy are much higher than the world average level and those of developed countries. 
variables of different years and "Industry" represents the dummy of different industries with subscript "I" represents the company I and " $\mathrm{t}$ " represents year $\mathrm{t}$.

The financial constraints are represented by three indicators ${ }^{3}$ : the ownership of the firm (state owned or not), the KZ index and the firm size. When the main stakeholder of the company is non-state, the $\mathrm{KZ}$ index is lower than the industry average and the firm's scale is lower than the industry average, the firm is assumed to face financial constraints, and the three financing constraints dummy variable are assigned 1. The HHI index is used to measure the Hertindahl Himchman Index, that is $H H I=\sum\left(O R_{i} / O R\right)$, in which $O R=\sum O R_{i}$, representing the main business income of the firm. The smaller the HHI index, the stronger is the market competition. Control variables were taken from the firm size, non-debt tax shield, asset yield, the proportion of tangible assets, the proportion of large shareholders and tax rates. Table1 summarizes the description of all variables.

Table 1. Variable definition

\begin{tabular}{|c|c|c|c|}
\hline Variable & Name & Acronym & Definition \\
\hline $\begin{array}{l}\text { dependent } \\
\text { variable }\end{array}$ & Capital leverage & Lev & Total liabilities over total assets \\
\hline \multirow{6}{*}{$\begin{array}{l}\text { independent } \\
\text { variable }\end{array}$} & Firm growth & $\begin{array}{l}\text { Growth } \\
\text { TQ }\end{array}$ & $\begin{array}{l}\text { Current operating income over operating income for the previous year }-1 \\
\text { (Book value of liabilities+ Market value of shareholders' equity) } \div \text { Book value of } \\
\text { total assets }\end{array}$ \\
\hline & Country growth & Sgdp & National GDP growth rate \\
\hline & Province growth & Pgdp & The GDP growth rate of the province where the firm is registered. \\
\hline & & & $\begin{array}{l}\text { The actual control of the firm is state-owned } \mathrm{Rz} 1=0, \text { or } \mathrm{Rz} 1=1 \\
\text { Firm pay individends } \mathrm{Rz} 2=0 \text {,or } \mathrm{Rz} 2=1\end{array}$ \\
\hline & Financing constraint & $\mathrm{Rz}$ & $\begin{array}{l}\text { According to the } \mathrm{Kz} \text { index (Kaplan \& Zingales, 1997), } \\
\text { When over the average of industry, Rz3=0,or Rz3=1 } \\
\text { Firm size over the average of industry, Rz4=0,or Rz4=1 }\end{array}$ \\
\hline & $\begin{array}{l}\text { product market } \\
\text { structure }\end{array}$ & HHI & $\begin{array}{l}H H I=\sum\left(O R_{i} / O R\right) \text {, where } \mathrm{OR}_{\mathrm{i}} \text { representing the main business income of the } \\
\text { firm }\end{array}$ \\
\hline \multirow{6}{*}{$\begin{array}{l}\text { control } \\
\text { variable }\end{array}$} & Firm size & Size & Natural logarithm of total assets of the firm \\
\hline & Non debt tax shield & Ndts & Depreciation over total assets \\
\hline & return on assets & Roa & Operating profit over total assets \\
\hline & Tangible assets ratio & Tangas & Net fixed assets over total assets \\
\hline & $\begin{array}{l}\text { The proportion of } \\
\text { large shareholders }\end{array}$ & First & The proportion of the largest shareholder \\
\hline & tax rate & Taxrate & The actual tax rate of firm \\
\hline
\end{tabular}

${ }^{3}$ According to Kaplan \& Zingales(1997), the index to measure financing constraint also includes whether paying cash dividends. This paper does not add this measurement, because Chinese listed companies which pay cash dividends are not widespread, and paying cash dividends is regarded as debt financing. This paper uses the difficulties of bank credit financing to measure the difference of financing constraint of Chinese listed companies. 
This financial data are from the RESSET database, and the national GDP growth rate and provincial GDP growth rate are from the National Statistical Yearbook. The sample of this paper is the non-financial listed companies in China's A-share market. We take 2003 as the starting year because all listed firms' actual controllers were required to be disclosed since then. The ending year is 2015 . All data are Winsor processed $([1 \%, 99 \%])$ to treat extreme values. The statistical descriptions of the variables are shown in Table 2.

As can be seen from Table 2, the variable financial leverage, "Lev", is higher than that of the US firm's average (Danis et al., 2014), which reflects that the indirect financing, for example, bank loan, is more common for Chinese firms. The variable "GDP" indicates that the growth rates are high, whether in the national level(Sgdp) or provincial level(Pgdp).

Table 2. Summary statistics

\begin{tabular}{|c|c|c|c|c|c|c|}
\hline Variables & Lev & Growth & TQ & Sgdp & Pgdp & HHI \\
\hline mean & 0.483 & 0.219 & 2.016 & 9.397 & 10.979 & 0.112 \\
\hline p25 & 0.484 & 0.123 & 1.380 & 9.5 & 11 & 0.072 \\
\hline p50 & 0.317 & -0.029 & 0.776 & 7.8 & 8.5 & 0.048 \\
\hline p75 & 0.635 & 0.305 & 2.454 & 10.6 & 13 & 0.126 \\
\hline sd & 0.228 & 0.611 & 2.007 & 1.994 & 2.729 & 0.126 \\
\hline $\mathrm{N}$ & 17595 & 17595 & 17595 & 17595 & 17595 & 17595 \\
\hline Variables & Size & Ndts & Roa & Tangas & First & Taxrate \\
\hline mean & 21.688 & 0.023 & 0.030 & 0.267 & 37.257 & 0.217 \\
\hline p25 & 21.545 & 0.020 & 0.032 & 0.235 & 35.19 & 0.25 \\
\hline p50 & 20.833 & 0.011 & 0.010 & 0.122 & 24.86 & 0.15 \\
\hline p75 & 22.368 & 0.032 & 0.060 & 0.384 & 49.12 & 0.25 \\
\hline sd & 1.242 & 0.016 & 0.068 & 0.183 & 15.731 & 0.069 \\
\hline $\mathrm{N}$ & 17595 & 17595 & 17595 & 17595 & 17595 & 17595 \\
\hline
\end{tabular}

Table 3 presents the Pearson correlation test results for each variable. As can be seen, the correlation coefficients between dependent variable (here $\triangle \mathrm{Lev}$ ) and independent variables (Growth, TQ, Sgdp and Pgdp) are all significant positive which mean that hypothesize 1 holds. Also, except Ndts and Tangas, the correlation coefficients between the variables are small, implying that collinearity may not be a serious problem in the regression analysis. In order to get more accurate test, new empirical tests include all control variables will be conducted in the latter part of this paper.

Table 3. Correlation matrix

\begin{tabular}{|c|c|c|c|c|c|c|c|c|c|c|c|}
\hline & Lev & $\triangle \mathrm{Lev}$ & Growth & TQ & Sgdp & Pgdp & Size & Ndts & Roa & Tangas & First \\
\hline$\triangle \mathrm{Lev}$ & $\begin{array}{l}0.44^{* * * *} \\
(0.00)\end{array}$ & & & & & & & & & & \\
\hline Growth & $\begin{array}{l}0.16^{* * * *} \\
(0.00)\end{array}$ & $\begin{array}{l}0.17^{* * * *} \\
(0.00)\end{array}$ & & & & & & & & & \\
\hline TQ & $\begin{array}{c}0.06^{* * * *} \\
(0.00)\end{array}$ & $\begin{array}{c}0.09^{* * *} \\
(0.00)\end{array}$ & $\begin{array}{c}0.07^{* * * *} \\
(0.00)\end{array}$ & & & & & & & & \\
\hline Sgdp & $\begin{array}{c}-0.29^{* * * * *} \\
(0.00)\end{array}$ & $\begin{array}{c}0.07^{* * *} \\
(0.00)\end{array}$ & $\begin{array}{c}-0.05^{* * * *} \\
(0.00)\end{array}$ & $\begin{array}{l}-0.01 \\
(0.44)\end{array}$ & & & & & & & \\
\hline Pgdp & $\begin{array}{c}-0.15^{* * * * *} \\
(0.00)\end{array}$ & $\begin{array}{c}0.04^{* * *} \\
(0.00)\end{array}$ & $\begin{array}{l}-0.02^{* * *} \\
(0.02)\end{array}$ & $\begin{array}{c}0.04^{* * * *} \\
(0.00)\end{array}$ & $\begin{array}{c}0.74^{* * * *} \\
(0.00)\end{array}$ & & & & & & \\
\hline Size & $\begin{array}{l}0.21^{* * *} \\
(0.00)\end{array}$ & $\begin{array}{l}0.02^{* * *} \\
(0.01)\end{array}$ & $\begin{array}{c}-0.02^{* * * *} \\
(0.00)\end{array}$ & $\begin{array}{c}-0.35^{* * * *} \\
(0.00)\end{array}$ & $\begin{array}{c}-0.19^{* * * * *} \\
(0.00)\end{array}$ & $\begin{array}{c}-0.18^{* * * *} \\
(0.00)\end{array}$ & & & & & \\
\hline Ndts & $\begin{array}{c}-0.28^{* * * *} \\
(0.00)\end{array}$ & $\begin{array}{c}-0.09^{* * * *} \\
(0.00)\end{array}$ & $\begin{array}{l}0.05^{* * * *} \\
(0.00)\end{array}$ & $\begin{array}{c}0.09^{* * * *} \\
(0.00)\end{array}$ & $\begin{array}{c}-0.02^{* * * * *} \\
(0.00)\end{array}$ & $\begin{array}{c}-0.04^{* * * * *} \\
(0.00)\end{array}$ & $\begin{array}{l}0.10^{* * * *} \\
(0.00)\end{array}$ & $\begin{array}{c}-0.14^{* * * * *} \\
(0.00)\end{array}$ & & & \\
\hline Roa & $\begin{array}{l}0.06^{* * *} \\
(0.00)\end{array}$ & $\begin{array}{c}-0.02^{* * * *} \\
(0.00)\end{array}$ & $\begin{array}{c}0.12^{* * * *} \\
(0.00)\end{array}$ & $\begin{array}{c}-0.03^{* * * *} \\
(0.00)\end{array}$ & $\begin{array}{c}0.12^{* * * *} \\
(0.00)\end{array}$ & $\begin{array}{l}0.12^{* * *} \\
(0.00)\end{array}$ & $\begin{array}{l}0.04^{* * *} \\
(0.00)\end{array}$ & & & & \\
\hline Tangas & $\begin{array}{c}0.07^{* * * *} \\
(0.00)\end{array}$ & $\begin{array}{c}-0.03^{* * * *} \\
(0.00)\end{array}$ & $\begin{array}{c}0.14^{* * *} \\
(0.00)\end{array}$ & $\begin{array}{c}-0.04^{* * * *} \\
(0.00)\end{array}$ & $\begin{array}{c}0.15^{* * *} \\
(0.00)\end{array}$ & $\begin{array}{c}0.17^{* * * *} \\
(0.00)\end{array}$ & $\begin{array}{c}0.09^{* * * *} \\
(0.00)\end{array}$ & $\begin{array}{c}0.77^{* * * *} \\
(0.00)\end{array}$ & $\begin{array}{c}-0.13^{* * * *} \\
(0.00)\end{array}$ & & \\
\hline First & $\begin{array}{l}-0.01 \\
(0.12)\end{array}$ & $\begin{array}{l}-0.01^{* *} \\
(0.05)\end{array}$ & $\begin{array}{c}0.00 \\
(0.71)\end{array}$ & $\begin{array}{l}-0.01^{*} \\
(0.06)\end{array}$ & $\begin{array}{l}0.05^{* * *} \\
(0.00)\end{array}$ & $\begin{array}{l}0.04^{* * *} \\
(0.00)\end{array}$ & $\begin{array}{l}0.23^{* * a} \\
(0.00)\end{array}$ & $\begin{array}{l}0.09^{* * *} \\
(0.00)\end{array}$ & $\begin{array}{l}0.12^{* * *} \\
(0.00)\end{array}$ & $\begin{array}{l}0.08^{* * * *} \\
(0.00)\end{array}$ & \\
\hline Taxrate & $\begin{array}{l}0.01^{* *} \\
(0.04)\end{array}$ & $\begin{array}{c}-0.04^{* * * *} \\
(0.00)\end{array}$ & $\begin{array}{c}-0.07^{* * *} \\
(0.00) \\
\end{array}$ & $\begin{array}{c}0.01 \\
(0.16) \\
\end{array}$ & $\begin{array}{c}0.28^{* * *} \\
(0.00)\end{array}$ & $\begin{array}{c}0.22^{* * *} \\
(0.00)\end{array}$ & $\begin{array}{l}0.00^{* * *} \\
(0.62)\end{array}$ & $\begin{array}{c}0.10^{* * *} \\
(0.00)\end{array}$ & $\begin{array}{c}-0.10^{* * * *} \\
(0.00)\end{array}$ & $\begin{array}{l}0.14^{* * *} \\
(0.00)\end{array}$ & $\begin{array}{c}0.04^{* * * *} \\
(0.00)\end{array}$ \\
\hline
\end{tabular}

This table reports the correlations matrix of the variables used in our analyses. $\triangle$ Lev is defined as leverage min lag one period of leverage.

Numbers in parentheses are probabilities. ${ }^{* * *}, * *$, and $*$ denote statistical significance at the $1 \%, 5 \%$, and $10 \%$ levels, respectively. 


\section{Empirical Results}

\subsection{The Effect of Growth to Capital Structure}

Table 4 is the results for empirical test of hypothesis H1 as the regression model (3.1). The first "(1) and (2)" columns of Table 4 are the main empirical results. We use the firm's revenue growth rate and the Tobin $\mathrm{Q}$ value test respectively. The results show that the regression coefficients of both growth and TQ values are significant positive (at $1 \%$ level), implying that the higher the company's growth, the higher the financial leverage. Columns (3) and (4) of Table 4 are the robustness tests for the study hypothesis H1, in which national GDP (SGDP) and provincial GDP (PGDP) are included, respectively.

The results show that the regression coefficients of the growth variables are positive, and the regression coefficients of the national GDP growth rate are tested by $1 \%$ significance level. The regression coefficient of the provincial GDP growth rate is through the 5\% significance level. Therefore, the hypothesis H1 is supported. This indicates that the optimal investment strategy is to invest immediately, rather than to wait. But the degree of marketization of the debt and equity markets is different, and the company is more likely to be able to obtain the bank credit-based bond financing, which led to increased financial leverage.

Of the control variables, the coefficient for "size" is significantly positive. According to the trade-off theory, the larger the firm is, the lower is the probability of incurring financial distress, and thus the higher is the financial leverage. The profitability of the firm's Roa regression is tested to be significantly negative, indicating that firms with higher profit will use internal resources first when financing. The coefficient with tangible asset, "Tangas", is significantly positive, implying that the firm's guarantee value is higher with bigger proportion of tangible assets, and thus easier to borrow, leading to a higher financial leverage eventually.

Table 4. The effect of growth to capital structure for Chinese listed firm

\begin{tabular}{|c|c|c|c|c|}
\hline $\begin{array}{c}\text { Lev } \\
\text { _cons }\end{array}$ & $\begin{array}{c}(1) \\
-0.511 \\
(-0.92)\end{array}$ & $\begin{array}{c}(2) \\
-2.832^{\text {**** }} \\
(-7.75)\end{array}$ & $\begin{array}{c}(3) \\
-0.990^{* * * *} \\
(-3.86)\end{array}$ & $\begin{array}{c}(4) \\
-0.980^{* * * *} \\
(-3.83)\end{array}$ \\
\hline L.Lev & $\begin{array}{c}0.193^{\text {**** }} \\
(9.65)\end{array}$ & $\begin{array}{c}0.146^{* * * *} \\
(8.93)\end{array}$ & $\begin{array}{c}0.776^{* * * *} \\
(19.49)\end{array}$ & $\begin{array}{l}0.766^{* * * *} \\
(19.62)\end{array}$ \\
\hline growth & $\begin{array}{l}0.013^{* * *} \\
(11.60)\end{array}$ & & & \\
\hline TQ & & $\begin{array}{c}0.052^{* * * *} \\
(15.44)\end{array}$ & & \\
\hline Sgdp & & & $\begin{array}{c}0.007^{* * *} \\
(5.26)\end{array}$ & \\
\hline Pgdp & & & & $\begin{array}{c}0.002^{* *} \\
(2.02)\end{array}$ \\
\hline Size & $\begin{array}{c}0.051^{* * * *} \\
(3.82)\end{array}$ & $\begin{array}{c}0.101^{* * * *} \\
(6.82)\end{array}$ & $\begin{array}{c}0.053^{* * * *} \\
(5.81)\end{array}$ & $\begin{array}{c}0.055^{* * * *} \\
(5.90)\end{array}$ \\
\hline Roa & $\begin{array}{l}-0.705^{* * *} \\
(-11.81)\end{array}$ & $\begin{array}{l}-0.661^{* * * *} \\
(-13.48)\end{array}$ & $\begin{array}{l}-0.892^{* * * *} \\
(-22.28)\end{array}$ & $\begin{array}{l}-0.908^{* * * *} \\
(-22.00)\end{array}$ \\
\hline Ndts & $\begin{array}{l}0.171 \\
(0.28)\end{array}$ & $\begin{array}{l}-0.514 \\
(-0.97)\end{array}$ & $\begin{array}{l}-0.473 \\
(-1.32)\end{array}$ & $\begin{array}{l}-0.557 \\
(-1.60)\end{array}$ \\
\hline Tangas & $\begin{array}{c}0.238^{* * * *} \\
(4.66)\end{array}$ & $\begin{array}{c}0.177^{* * * *} \\
(3.82)\end{array}$ & $\begin{array}{c}0.068^{* * * *} \\
(2.65)\end{array}$ & $\begin{array}{c}0.075^{* * * *} \\
(2.96)\end{array}$ \\
\hline First & $\begin{array}{l}-0.001 \\
(-1.12)\end{array}$ & $\begin{array}{l}0.001 \\
(0.17)\end{array}$ & $\begin{array}{c}0.001^{* * *} \\
(2.08)\end{array}$ & $\begin{array}{c}0.001^{* * *} \\
(2.16)\end{array}$ \\
\hline Taxrate & $\begin{array}{l}-0.012 \\
(-0.16)\end{array}$ & $\begin{array}{l}-0.022 \\
(-0.32)\end{array}$ & $\begin{array}{l}0.042 \\
(1.43)\end{array}$ & $\begin{array}{l}0.032 \\
(1.11)\end{array}$ \\
\hline $\begin{array}{l}\text { Year fixed Effect } \\
\text { Industry fixed Effect }\end{array}$ & $\begin{array}{l}\text { controlled } \\
\text { controlled }\end{array}$ & $\begin{array}{l}\text { controlled } \\
\text { controlled }\end{array}$ & $\begin{array}{l}\text { controlled } \\
\text { controlled }\end{array}$ & $\begin{array}{l}\text { controlled } \\
\text { controlled }\end{array}$ \\
\hline $\operatorname{AR}(1)$ & 0.051 & 0.024 & 0.031 & 0.018 \\
\hline $\operatorname{AR}(2)$ & 0.221 & 0.121 & 0.282 & 0.173 \\
\hline Sargan & 0.432 & 0.547 & 0.631 & 0.531 \\
\hline Obs & 17595 & 17595 & 17595 & 17595 \\
\hline
\end{tabular}

The number in parentheses is $\mathrm{Z} . * * *, * *$, and $*$ denote statistical significance at the $1 \%, 5 \%$, and $10 \%$ levels, respectively. 


\subsection{The Effect of Financing Constraints on the Relation of Growth and Capital Structure}

Table 5 is the regression result of testing $\mathrm{H} 2$, in which column (1) and (2) use the nature of actual controller to represent financing constraints. Only non-state owned listed firms are assumed to face financing constraints, and takes 1; state owned listed firms take the value of 0 . Column (3) and (4) consider KZ index, with the assumption that the higher KZ, the tighter constraints. Rz2 takes value 1 if $\mathrm{KZ}$ is above average and 0 otherwise. Column (5) and (6) take "size" into account, and assume that smaller firms face tighter constraints. Thus, it takes 1 if the size of the firm is smaller than the average size and 0 otherwise.

Table 5 shows that the coefficients for the entire cross terms except column (4) and (5) are negative (exceeding the 1\% significance level). This means that the tighter financing constraints the firm faces, the higher growth and higher leverage the firm tends to have. That is, the firm with stronger financing constraints has a stronger positive effect on the correlation between capital structure and growth. Hypothesis H2 is supported. Furthermore, the results show that, when high growth firms face tighter financing constraints, their debt will be lower not only because of the high revenue growth, but also because of the difficulty of obtaining external debt. Moreover, GROWTH and TQ are tested at $1 \%$ significance level and further support hypothesis H1 .

Table 5. The effect of financing constraints on the relation of growth and capital structure

\begin{tabular}{|c|c|c|c|c|c|c|}
\hline & & & & & & \\
\hline $\begin{array}{l}\text { Lev } \\
\text { _cons }\end{array}$ & $\begin{array}{c}(1) \\
-1.230^{* *} \\
(-2.18)\end{array}$ & $\begin{array}{c}(2) \\
-2.083^{* * * *} \\
(-6.00)\end{array}$ & $\begin{array}{c}(3) \\
-0.707^{*} \\
(-1.65)\end{array}$ & $\begin{array}{c}(4) \\
-1.481^{* * * *} \\
(-4.30)\end{array}$ & $\begin{array}{c}(5) \\
-1.006^{*} \\
(-1.72)\end{array}$ & $\begin{array}{c}(6) \\
-1.630^{* * *} \\
(-4.23)\end{array}$ \\
\hline L.Lev & $\begin{array}{c}0.188^{* * * *} \\
(9.17)\end{array}$ & $\begin{array}{c}0.145^{* * * *} \\
(8.53)\end{array}$ & $\begin{array}{c}0.166^{* * * *} \\
(8.80)\end{array}$ & $\begin{array}{c}0.127^{* * * *} \\
(8.33)\end{array}$ & $\begin{array}{c}0.185^{* * * *} \\
(9.21)\end{array}$ & $\begin{array}{c}0.136^{* * *} \\
(8.44)\end{array}$ \\
\hline Growth & $\begin{array}{l}0.018^{* * * *} \\
(8.61)\end{array}$ & & $\begin{array}{l}0.044^{* * * *} \\
(6.94)\end{array}$ & & $\begin{array}{l}0.012^{* * * *} \\
(9.23)\end{array}$ & \\
\hline TQ & & $\begin{array}{c}0.071^{* * * *} \\
(15.72)\end{array}$ & & $\begin{array}{c}0.053^{* * * *} \\
(13.92)\end{array}$ & & $\begin{array}{c}0.069^{* * *} \\
(16.01)\end{array}$ \\
\hline Rz1 & $\begin{array}{l}-0.010 \\
(-0.38)\end{array}$ & $\begin{array}{l}0.009 \\
(0.32)\end{array}$ & & & & \\
\hline Growth*Rz1 & $\begin{array}{c}-0.009^{* * *} \\
(-3.68)\end{array}$ & & & & & \\
\hline $\mathrm{TQ} * \mathrm{Rz} 1$ & & $\begin{array}{c}-0.030^{* * * *} \\
(-5.93)\end{array}$ & & & & \\
\hline Rz2 & & & $\begin{array}{c}0.066^{* * *} \\
(8.41)\end{array}$ & $\begin{array}{c}0.070^{* * * *} \\
(8.80)\end{array}$ & & \\
\hline Growth*Rz2 & & & $\begin{array}{c}-0.036^{* * * *} \\
(-5.63)\end{array}$ & & & \\
\hline $\mathrm{TQ} * \mathrm{Rz} 2$ & & & & $\begin{array}{l}-0.004 \\
(-0.93)\end{array}$ & & \\
\hline Rz3 & & & & & $\begin{array}{l}-0.005 \\
(-0.35)\end{array}$ & $\begin{array}{l}0.004 \\
(0.30)\end{array}$ \\
\hline Growth*Rz3 & & & & & $\begin{array}{l}0.003 \\
(1.37)\end{array}$ & \\
\hline $\mathrm{TQ}{ }^{*} \mathrm{Rz} 3$ & & & & & & $\begin{array}{c}-0.024^{* * *} \\
(-5.17)\end{array}$ \\
\hline Size & $\begin{array}{c}0.053^{* * *} \\
(4.07)\end{array}$ & $\begin{array}{c}0.100^{* * * *} \\
(6.80)\end{array}$ & $\begin{array}{l}0.022^{*} \\
(1.78)\end{array}$ & $\begin{array}{c}0.095^{* * * *} \\
(6.57)\end{array}$ & $\begin{array}{c}0.042^{* * * *} \\
(2.82)\end{array}$ & $\begin{array}{c}0.106^{* * * *} \\
(6.67)\end{array}$ \\
\hline Roa & $\begin{array}{l}-0.691^{\text {***** }} \\
(-12.27)\end{array}$ & $\begin{array}{l}-0.646^{* * * *} \\
(-13.34)\end{array}$ & $\begin{array}{l}-0.647^{* * * *} \\
(-12.32)\end{array}$ & $\begin{array}{l}-0.578^{* * *} \\
(-12.10)\end{array}$ & $\begin{array}{c}-0.687^{* * * *} \\
(-11.99)\end{array}$ & $\begin{array}{c}-0.649^{* * * *} \\
(-13.25)\end{array}$ \\
\hline Ndts & $\begin{array}{l}-0.112 \\
(-0.18)\end{array}$ & $\begin{array}{l}-0.743 \\
(-1.38)\end{array}$ & $\begin{array}{l}-0.456 \\
(-0.77)\end{array}$ & $\begin{array}{l}-0.698 \\
(-1.38)\end{array}$ & $\begin{array}{l}-0.034 \\
(-0.05)\end{array}$ & $\begin{array}{l}-0.438 \\
(-0.82)\end{array}$ \\
\hline Tangas & $\begin{array}{c}0.233^{* * * *} \\
(4.39)\end{array}$ & $\begin{array}{c}0.169^{* * * *} \\
(3.61)\end{array}$ & $\begin{array}{c}0.347^{* * * *} \\
(6.55)\end{array}$ & $\begin{array}{c}0.267^{* * * *} \\
(5.56)\end{array}$ & $\begin{array}{c}0.237^{* * * *} \\
(4.48)\end{array}$ & $\begin{array}{c}0.173^{* * * *} \\
(3.79)\end{array}$ \\
\hline First & $\begin{array}{l}-0.001 \\
(-0.98)\end{array}$ & $\begin{array}{l}0.000 \\
(0.28)\end{array}$ & $\begin{array}{l}-0.001 \\
(-1.45)\end{array}$ & $\begin{array}{l}-0.000 \\
(-0.21)\end{array}$ & $\begin{array}{l}-0.001 \\
(-1.03)\end{array}$ & $\begin{array}{l}0.000 \\
(-0.11)\end{array}$ \\
\hline Taxrate & $\begin{array}{l}-0.011 \\
(-0.15)\end{array}$ & $\begin{array}{l}-0.025 \\
(-0.37)\end{array}$ & $\begin{array}{l}-0.021 \\
(-0.29)\end{array}$ & $\begin{array}{l}-0.018 \\
(-0.27)\end{array}$ & $\begin{array}{l}-0.018 \\
(-0.24)\end{array}$ & $\begin{array}{l}-0.032 \\
(-0.47)\end{array}$ \\
\hline $\begin{array}{l}\text { Year fixed Effect } \\
\text { Industry fixed Effect }\end{array}$ & $\begin{array}{l}\text { controlled } \\
\text { controlled }\end{array}$ & $\begin{array}{l}\text { controlled } \\
\text { controlled }\end{array}$ & $\begin{array}{l}\text { controlled } \\
\text { controlled }\end{array}$ & $\begin{array}{l}\text { controlled } \\
\text { controlled }\end{array}$ & $\begin{array}{l}\text { controlled } \\
\text { controlled }\end{array}$ & $\begin{array}{l}\text { controlled } \\
\text { controlled }\end{array}$ \\
\hline $\mathrm{AR}(1)$ & 0.009 & 0.014 & 0.021 & 0.036 & 0.023 & 0.032 \\
\hline $\operatorname{AR}(2)$ & 0.324 & 0.453 & 0.489 & 0.524 & 0.529 & 0.615 \\
\hline Sargan & 0.524 & 0.653 & 0.589 & 0.624 & 0.632 & 0.745 \\
\hline Obs & 17595 & 17595 & 17595 & 17595 & 17595 & 17595 \\
\hline
\end{tabular}


The number in parentheses is $\mathrm{Z} . * * *, * *$, and $*$ denote statistical significance at the $1 \%, 5 \%$, and $10 \%$ levels, respectively.

\subsection{The Effect of Product Market Structure on the Relation of Growth and Capital Structure}

Table 6 is the empirical tests of the hypothesis H3, or equation (3.3). As can be seen from Table 6, the cross products of the two growth indicators and product market structure indicators are significantly negative (at the 5\% significance level of), indicating that when the industry is more competitive, that is, with smaller HHI index, and higher growth, the firm tends to have higher leverage. Therefore, hypothesis H3 is also supported. The reason is that the high growth firms face stronger competition, and thus have stronger desire to invest immediately to gain the first mover advantage. Therefore, when facing equity financing constraints, the firms prefer the debt financing, which is of higher degree of marketization, and this will result in a higher financial leverage. Similarly, both Growth and TQ of Table 5 yielded a $1 \%$ significance level, implying that $\mathrm{H} 1$ is again supported.

Table 6. The effect of product market structure on the relation of growth and capital structure

\begin{tabular}{|c|c|c|}
\hline Lev & (1) & (2) \\
\hline _cons & $\begin{array}{c}-1.133^{* * *} \\
(-4.13)\end{array}$ & $\begin{array}{c}-3.080^{* * * *} \\
(-10.53)\end{array}$ \\
\hline L.Lev & $\begin{array}{c}0.184^{* * * *} \\
(9.93)\end{array}$ & $\begin{array}{c}0.139^{* * * *} \\
(9.11)\end{array}$ \\
\hline Growth & $\begin{array}{c}0.015^{* * * *} \\
(9.91)\end{array}$ & \\
\hline TQ & & $\begin{array}{c}0.056^{* * * *} \\
(15.74)\end{array}$ \\
\hline HHI & $\begin{array}{c}-0.110^{* *} \\
(-2.23)\end{array}$ & $\begin{array}{l}-0.058 \\
(-1.08)\end{array}$ \\
\hline Growth* HHI & $\begin{array}{c}-0.017^{\text {*** }} \\
(-2.28)\end{array}$ & \\
\hline TQ* HHI & & $\begin{array}{c}-0.035^{* *} \\
(-2.34)\end{array}$ \\
\hline Size & $\begin{array}{c}0.051^{* * * *} \\
(3.99)\end{array}$ & $\begin{array}{c}0.109^{* * * *} \\
(7.98)\end{array}$ \\
\hline Roa & $\begin{array}{l}-0.715^{* * * *} \\
(-12.72)\end{array}$ & $\begin{array}{c}-0.656^{* * * *} \\
(-12.66)\end{array}$ \\
\hline Ndts & $\begin{array}{l}-0.419 \\
(-0.74)\end{array}$ & $\begin{array}{l}-0.276 \\
(-0.52)\end{array}$ \\
\hline Tangas & $\begin{array}{c}0.248^{* * * *} \\
(5.29)\end{array}$ & $\begin{array}{c}0.165^{* * * *} \\
(3.62)\end{array}$ \\
\hline First & $\begin{array}{l}-0.001 \\
(-1.41)\end{array}$ & $\begin{array}{l}-0.000 \\
(-0.01)\end{array}$ \\
\hline Taxrate & $\begin{array}{l}-0.044 \\
(-0.60)\end{array}$ & $\begin{array}{l}-0.033 \\
(-0.48)\end{array}$ \\
\hline Year fixed Effect & controlled & controlled \\
\hline $\operatorname{AR}(1)$ & 0.002 & 0.010 \\
\hline $\operatorname{AR}(2)$ & 0.374 & 0.514 \\
\hline Sargan & 0.538 & 0.631 \\
\hline Obs & 17595 & 17595 \\
\hline
\end{tabular}

The number in parentheses is $\mathrm{Z} . * * *, * *$, and * denote statistical significance at the $1 \%, 5 \%$, and $10 \%$ levels, respectively.

\subsection{Growth and Capital Structure for High-Tech Firms}

For robustness check, we select the high-tech firms because of their higher growth, lower proportion of tangible assets, and stronger financing constraints. In particular, we select out the 417 firms either in medicine and biological products sector (C8) or information technology sector (G). Table 7 shows the empirical results of the relationship between the growth and capital structure for these firms. It can be seen that the regression coefficients of both the growth and TQ values of both growth indices are positive and pass the $1 \%$ significance level test, strongly indicating that he stronger the growth, the higher the company's financial leverage. 
Table 7. Growth and capital structure for high-tech firms

\begin{tabular}{|c|c|c|}
\hline$\overline{\text { Lev }}$ & Growth & TQ \\
\hline \multirow{2}{*}{ _cons } & $-1.502^{* * *}$ & $-3.321^{\text {**** }}$ \\
\hline & $(-2.40)$ & $(-4.70)$ \\
\hline \multirow{2}{*}{ L.Lev } & $0.330^{* * * *}$ & $0.262^{* * * *}$ \\
\hline & $(7.16)$ & $(6.87)$ \\
\hline \multirow{2}{*}{ Growth } & $0.020^{* * * *}$ & \\
\hline & $(3.10)$ & \\
\hline \multirow[t]{2}{*}{ TQ } & & $0.022^{* * *}$ \\
\hline & & $(6.08)$ \\
\hline \multirow[t]{2}{*}{ Size } & 0.032 & $0.111^{* * * *}$ \\
\hline & (1.17) & $(3.48)$ \\
\hline \multirow[t]{2}{*}{ Roa } & $-0.441^{* * * *}$ & $-0.389^{* * *}$ \\
\hline & $(-3.10)$ & $(-2.25)$ \\
\hline \multirow{2}{*}{ Ndts } & 1.671 & 3.691 \\
\hline & $(0.76)$ & (1.60) \\
\hline \multirow{2}{*}{ Tangas } & 0.170 & 0.012 \\
\hline & (1.06) & $(0.07)$ \\
\hline \multirow{2}{*}{ First } & $-0.005^{\text {** }}$ & -0.002 \\
\hline & $(-2.12)$ & $(-0.88)$ \\
\hline \multirow{2}{*}{ Taxrate } & 0.199 & 0.238 \\
\hline & $(1.28)$ & (1.63) \\
\hline Year fixed Effect & controlled & controlled \\
\hline $\operatorname{AR}(1)$ & 0.015 & 0.032 \\
\hline $\mathrm{AR}(2)$ & 0.241 & 0.325 \\
\hline Sargan & 0.477 & 0.521 \\
\hline Obs & 2212 & 2212 \\
\hline
\end{tabular}

The number in parentheses is $\mathrm{Z} . * * *, * *$, and $*$ denote statistical significance at the $1 \%, 5 \%$, and $10 \%$ levels, respectively.

\section{Conclusion}

As an emerging economy, China's growth is relatively higher, which creates a predictable steady growth environment for Chinese firms. Thus, Chinese firms prefer immediate investment rather than delayed investment. Meanwhile, the marketization process of China's bank credit leads ahead of the stock market. Therefore, Chinese listed firms generally have high financial leverage, and the financial leverage and the growth are positively correlated. When a listed firm is faced with financial constraints, or in a more competitive product market, the positive correlation between its growth and its financial leverage becomes even stronger. The robustness check, in which part the high-tech industries are concentrated, supports the above hypothesis.

Not only the results can be helpful for the listed firms, for example, firms with high competition should focus on the timing, not the cost, to take the first mover advantage; but also the research findings of this paper can serve as policy guidance for Chinese financial authorities. Since China's stock market lags behind in terms of its marketization process, the authority should let the market play a bigger role, instead of relying on the lengthy administration process, to shorten the financing duration.

\section{Acknowledgements}

The authors thank seminar participants at School of Business, ECUST, for helpful comments. The authors acknowledge the sponsorship by National Science Foundation of China (Grant No. 71702056), Ministry of Education of China (18YJC790230), Shanghai Planning Office of Philosophy and Social Science (Grant No. 2016EJB004).

\section{References}

Barraclough, K. (2007). Scaling regression equations: Solution or problems? [J]. 2007, Working Paper, Vanderbilt University.

Bo, H., Huang, Z. N., \& Wang, C. Y. (2011). Understanding seasoned equity offerings of Chinese firms [J]. Journal of Banking \& Finance, 35, 1143-1157. https://doi.org/10.1016/j.jbankfin.2010.09.025

Booth, L., Aivazian, V., Demirguc-Kunt, A., \& Maksimovic, V. (2001). Capital Structures in Developing Countries[J]. The Journal of Finance, 56(1), 87-130. https://doi.org/10.1111/0022-1082.00320

Chang C., Chen X., \& Liao, G. M. (2014). What are the reliably important determinants of capital structure in china?[J]. Pacific-Basin Finance Journal, 30, 87-113. https://doi.org/10.1016/j.pacfin.2014.06.001 
Chang, C., Liao, G. M., Yu, X. Y., \& Ni, Z. (2014). Information from Relationship Lending: Evidence from Loan Defaults in China [J]. Journal of Money, Credit and Banking, 46(6), 1225-1257. https://doi.org/10.1111/jmcb.12139

Chen, M. (2014). Estimation of Nonlinear Panel Models with Multiple Unobserved Effects [J]. 2014, memo.

Chen, X. Y., \& Ling, X. (2017). Determinants of Chinese equity financing behaviors: traditional model and the alternatives [J]. Accounting and Finance, 57, 69-100. https://doi.org/10.1111/acfi.12151

Danis, A., \& Rettl, D. A. (2014). Whited T Refinancing, profitability, and capital structure [J]. Journal of Financial Economics, 114(3), 424-443. https://doi.org/10.1016/j.jfineco.2014.07.010

Dong, Y., Liu, Z. T., \& Shen, Z. S. Q. (2016). Does State Ownership Really Matter in Determining Access to Bank Loans? Evidence from China's Partial Privatization [J]. Pacific-Basin Finance Journal, 40, 73-85. https://doi.org/10.1016/j.pacfin.2016.09.001

Dybvid, P., Shan, S. C. Y., \& Tang, D. Y. J. (2011). Does Informal Finance Help Formal Finance? Evidence from Third Party Loan Guarantees in China[C]. The 2nd Capital Markets Program Meeting and Corporate Finance Program Meeting, Kunming, China, 14-15 July 2011.

Fonseka, M. M., Yang, X., Tian, G. L., \& Colombage, S. R. N. (2015). Political connections, ownership structure and private-equity placement decision: evidence from Chinese listed firms[J]. Applied Economics, 47(52), 5648-5666. https://doi.org/10.1080/00036846.2015.1054073

Gaur, A. S., Malhotra, S., \& Zhu, P. (2013). Acquisition announcements and stock market valuations of acquiring firms' rivals: A test of the growth probability hypothesis in China [J]. Strategic Management Journal, 34, 215-232. https://doi.org/10.1002/smj.2009

Hovey, M. (2007). Leverage, Profitability and the Ownership Structures of Listed Firms in China[C].20th Australasian Finance \& Banking Conference 2007 Paper. https://doi.org/10.2139/ssrn.1009432

Hsiao, C., Shen, Y., \& Bian, W. L. (2015). Evaluating the effectiveness of China's financial reform reform-The efficiency of China's domestic banks[J]. China Economic Review, 35, 70-82. https://doi.org/10.1016/j.chieco.2015.05.006

Huang, G. H., \& Song, F. M. (2006). The determinants of capital structure: Evidence from China [J]. China Economic Review, 17(1), 14-36. https://doi.org/10.1016/j.chieco.2005.02.007

Huang, W., Boateng, A., \& Newman, A. (2016). Capital structure of Chinese listed SMEs: an agency theory perspective [J]. Small Business Economics, 47, 535-550. https://doi.org/10.1007/s11187-016-9729-6

Jiang, F. X., Kim, K. A., Nofsinger, J. R., \& Zhu, B. (2015). Product market competition and corporate investment: evidence from China [J]. Journal of Corporate Finance, 35, 196-210. https://doi.org/10.1016/j.jcorpfin.2015.09.004

Kaplan, S. N., \& Zingales, L. (1997). Do Investment-Cash Flow Sensitivities Provide Useful Measures of Financing Constraints? [J]. The Quarterly Journal of Economics, 112(1), 169-215. https://doi.org/10.1162/003355397555163

Kim, W., \& Weisbach, M. S. (2008). Motivations for public equity offers: An international perspective [J]. Journal of Financial Economics, 87(2), 281-307. https://doi.org/10.1016/j.jfineco.2006.09.010

Li, Z. (2011). Legislative Impact on Lending: Credit Risk Management in China [J]. Review of Pacific Basin Financial Markets and Policies, 14(4), 617-645. https://doi.org/10.1142/S0219091511002342

Myers, S. C. (1977). Determinants of corporate borrowing [J]. Journal of Financial Economics, 5(2), 147-175. https://doi.org/10.1016/0304-405X(77)90015-0

Myers, S. C. (1984). The capital structure puzzle [J]. The Journal of Finance, 39, 575-592. https://doi.org/10.2307/2327916

Myers, S. C., \& Majluf, N. S. (1984). Corporate financing and investment decisions when firms have information that investors do not have [J]. Journal of Financial Economics, 13, 187-221. https://doi.org/10.1016/0304-405X(84)90023-0

Pessarossi, P., \& Weill, L. (2013). Choice of corporate debt in China: The role of state ownership [J]. China Economic Review, 26, 1-16. https://doi.org/10.1016/j.chieco.2013.03.005

Qian, J., Strahan, P. E., \& Yang, Z. S. (2015). The Impact of Incentives and Communication Costs on Information Production and Use: Evidence from Bank Lending [J]. The Journal of Finance, 70(4), 1457-1493. https://doi.org/10.1111/jofi.12251 
Qian, Y., Tian, Y., \& Wirjanto, T. S. (2009). Do Chinese publicly listed firms adjust their capital structure toward a target level? [J]. China Economic Review, 20, 662-676. https://doi.org/10.1016/j.chieco.2009.06.001

Strebulaev, I. A. (2007). Do Tests of Capital Structure Theory Mean What They Say? [J]. The Journal of Finance, 62(4), 1747-1787. https://doi.org/10.1111/j.1540-6261.2007.01256.x

Titman, S., \& Wessels, R. (1988). The Determinants of Capital Structure Choice [J]. The Journal of Finance, 43(1), 1-19. https://doi.org/10.1111/j.1540-6261.1988.tb02585.x

Tong, G. Q. (2005). Green C Pecking order or trade-off hypothesis? Evidence on the capital structure of Chinese firms [J]. Applied Economics, 37, 2179-2189. https://doi.org/10.1080/00036840500319873

Wintoki, M. B., Linck, J. S., \& Netter, J. M. (2012). Endogeneity and the dynamics of internal corporate governance [J]. Journal of Financial Economics, 105(3), 581-606. https://doi.org/10.1016/j.jfineco.2012.03.005

Zhu, Y. S. (2012). Capital structure: The case of firms issuing debt [J]. Australian Journal of Management, 37(2), 283-295. https://doi.org/10.1177/0312896211429159

Zou, H., \& Xiao, J. Z. H. (2006). The financing behavior of listed Chinese firms [J]. The British Accounting Review, 38(3), 239-258. https://doi.org/10.1016/j.bar.2006.04.008

\section{Copyrights}

Copyright for this article is retained by the author(s), with first publication rights granted to the journal.

This is an open-access article distributed under the terms and conditions of the Creative Commons Attribution license which permits unrestricted use, distribution, and reproduction in any medium, provided the original work is properly cited. 